\title{
THE PROBLEM OF ENVIRONMENTAL SAFETY OF THE FIELDS OF MINING INDUSTRIAL PRODUCTION OF ARID ZONE OF KAZAKHSTAN
}

\author{
Roza BEXEITOVA*, Larisa VESELOVA, Khaini-Kamal KASSYMKANOVA, \\ Gulnar JANGULOVA, Gulbanu BAIDAULETOVA, Yermek ZHALGASBEKOV, \\ Shugyla BURLIBAYEVA, Venera TUREKHANOVA \\ Al-Farabi Kazakh National University, Almaty, Kazakhstan
}

Received 06 August 2018; accepted 15 November 2018

\begin{abstract}
The urgency of the safety of the components of the natural environment of Central Kazakhstan is due, firstly, to the long development of solid minerals and, in connection with this, the huge expenditure of energy and water resources, and secondly, to the use of obsolete mining technologies. The complex of works on the extraction of solid minerals leads to a change in the entire range of environmental conditions in the mining areas and adjacent areas, which is due to the interconnectedness of all natural components among themselves.

The article deals with the processes, associated with work in the mining industry, the beginning of which was laid in the first half of the XX century. A prolonged mechanical intervention in the surface, subsurface structures of the earth's crust led to the development of a number of dangerous geodynamic processes, that directly and indirectly degrade the ecological state of the surrounding area.
\end{abstract}

Keywords: solid minerals, subarid and arid conditions, mining production, the method of extraction of ores, the morphology of the relief, pollution, groundwater and surface water, dumps, metal industry, lithogenic basis, technological impact.

\section{Introduction}

Long-term development and enrichment of ores (nonferrous, polymetallic and rare-metal) and coal in the region requires significant energy and water costs. Actually all types of economic activities, including using water, in one way or another, lead to chemical pollution (in various ranges) of the environment. According to M. I. Lvovich (1986, p. 214) for the primary processing of ores and the extraction of 1 ton of the useful component, 8 tons of water and more than $1000 \mathrm{~kW}$ of energy are required. This is especially important for the region of Central Kazakhstan, which is characterized by a dry climate and due to the fact that the outdated technology is used until today. The limited surface water resources of the territory have led the mining industry to the active and large-scale using of groundwater, which has led the waters of the main rivers and reservoirs of the region to life-threatening pollution. The sources of pollution of components of the environment include not only the functioning metallurgical enterprises of international corporations such as "Kazakhmys",
"Kazzinc", "ArcelorMittal", but also a big waste of mining metallurgical production.

The problem of the ecological state of the geographic environment as a result of human intervention in the surface and near-surface structures of the crust of the earth was taken up by many native and foreign researchers (Abalakov \& Kuzmin, 1998, Abalakov, 2007; Adamenko, 1991; Azbukina \& Fedorov, 1975; Grishin \& Novikov, 2000; Rodionov, 2000; Smetanin, 2000; Hotuntsev, 2004; Nysanbek, 2003; Efremov, 2008; Eszhanova, 2010; Evseeva, 2012; Simonov, 1990, 2005; Simonov \& Simonova, 2013; Golubev, 2008; Korkin \& Talyneva, 2015; Akiyanova, 2000; Kushimova, 2003; Milanovich, 2000; Toy, 1984; Charles, Hughes, \& Burford, 1984; Shogren \& Grocken, 1999; Graham \& Kiney, 1980; Simonov \& Gladkevitch, 1995; Pecsi, 1986; Barsch, 1990; Gurney, 2005; Bocco, Velbzquez, \& Siebe, 2005; Volkov, 2009; Fonstad, Dietrich, Courville, Jensen, \& Carbonneau, 2013; Baborykin, 2013; Ermolov, 2014; Kaiser et al., 2014; Smith \& Vericat, 2015; Voskresenskiy, Suchilin, Ushakova, Shaforostov, \& Entin, 2018; etc.).

*Corresponding author. E-mail: bexeitova.roza@gmail.com 


\section{Territory and direction of the research}

The territory of research, which is rich in ore and nonore deposits, is the largest mining industrial region of the republic (Figure 1). The area of territory of research is almost 0.2 part ( 545 thousand $\mathrm{km}^{2}$ ) of the total area of the Republic of Kazakhstan.

The continental climate of the region is characterized by significant temperature differences: from $-38^{\circ}-45^{\circ} \mathrm{C}$ in winter to $+37^{\circ}+44^{\circ} \mathrm{C}$ in summer. Low-snowy winters (the thickness of the snow cover is not more than $15-20 \mathrm{~cm}$ ) are characterized by strong winds. Snow cover usually has a thickness of $-30 \mathrm{~cm}-12 \mathrm{~cm}$. Short-term rain showers, dry and dusty winds are characteristic of a hot summer, a significant amount of evaporation $(1,400 \mathrm{~mm})$, exceeding the average annual amount of precipitation $(200 \mathrm{~mm})$ by almost 6-7 times (Institute of geography, 2010).

The ore richness of the area is due to the structures of the platform shield, the basal layers of which include various types of minerals - copper, zinc, plumbum, molybdenum, manganese and wolfram, which are mined both by surface and underground methods (Figure 1). In the north of the territory of research is the Karaganda coal basin, in which the development of coal has been conducted since the 30s of the last century (Bekseitova, Veselova, Duisebaeva, Baiandinova, \& Bekkulieva, 2012).

The relief of the territory is flat, broken by low elevations, which are the result of neotectonic uplifts. The highest point of the territory is 1500 meters, and the average height is 500 meters above sea level.

The features of the soil and vegetation cover of the territory are determined by the continental climate. Soils clarified brown high alkalinity, have heavy texture and very low content of humus (2-3\%). Intensive industrial development of the region led to damage to the soil cover.
This is especially true of those mining areas where the surface of the earth is periodically covered with fresh technogenic sediments (Medeu, 2010; Faizov, 2000).

The researches were aimed at studying the general state of ecological safety of the territory of Central Kazakhstan, which has differences by its long-term mining industry in the context of extensive development of solid minerals and an unfavorable arid climate. The study of the problem was based on the data of cartographic and bibliographic sources, long-term field studies, on the reporting and stock materials of industrial organizations and the determination of the relative assessment of the ecological state of the environment within the mining zones.

\section{Materials and methods}

Mining developments in the territory of research, which began in the first half of the twentieth century, were localized mainly by industrial sites. Ecological consequences of both direct and indirect impacts were extremely rare, especially on large areas located outside the mining industry.

The general area of direct development of coal and ores within the industrial zones of the region (Zhezkazgan-Ulytau, Karaganda-Temirtau, Balkhash-Sayak) is $928 \mathrm{~km}^{2}$, and taking into account the entire service infrastructure - more than $4,500 \mathrm{~km}^{2}$.

Waste from mining and processing of raw materials in the mining industry (coal and non-ferrous metals) accumulated over 60 years. The total amount of waste during this time is at least 7 billion tons, considering that from one ton of ore $96-97 \%$ is spent on waste. In the coal mining industry, the production of 1 ton of coal is accompanied by 3 tons of waste and methane emissions (Saginov, 1995). A significant part of unnecessary industrial landfills

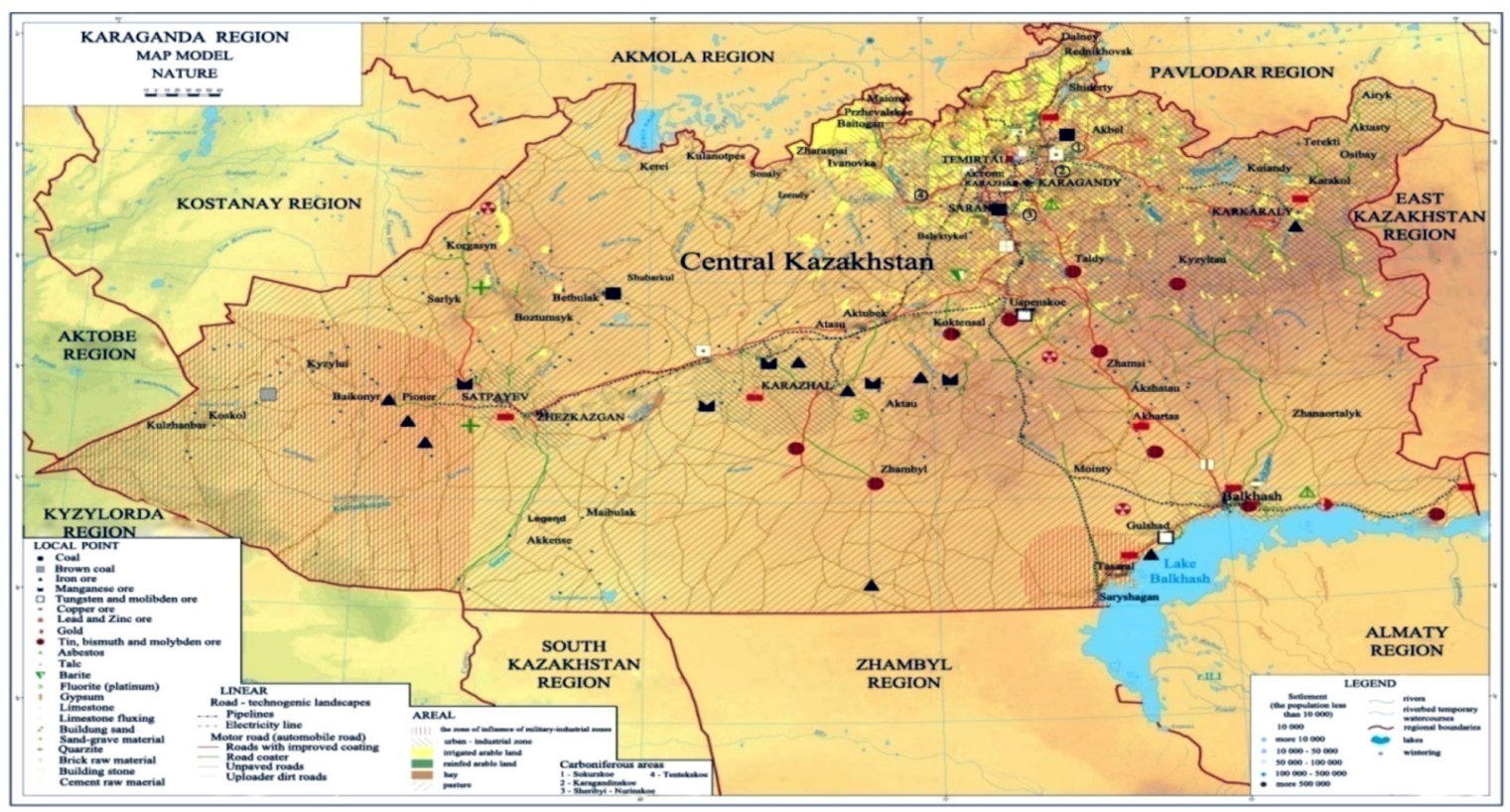

Figure 1. Resource base of Central Kazakhstan 
are located near major cities such as Karaganda, Zhezkazgan, Satbayev and Temirtau. In nonferrous metallurgy ore raw materials contain a high concentration of toxic substances in the waste. Despite of this, the materials from dumps are widely used in road construction and for leveling the earth's surface in industrial and civil construction. The result is a high level of cancer diseases of the population, pollution of surface and groundwater, degradation of soil and vegetation cover within industrial zones.

The complex of works on the extraction of solid minerals in arid climate conditions leads to a change in the whole complex of natural conditions. Excavation and accumulation of rock masses represents a change in geological and geomorphological conditions; protection of mining objects from flooding (pumping of mine and ground water) - changing the hydrological and hydrogeological conditions of the region. The springs are disappearing (1/3 of all springs of the Ulytau rock-hill massif), rivers and lakes are getting shallower, the groundwater level has significantly decreased (from 3-5 $\mathrm{m}$ to $12-15 \mathrm{~m}$ ), karst develops, suffusion, soil salinization and many other adverse ,sometimes dangerous processes that cause rapid transformation and deformation of the upper crustal layer and relief-forming elements. It has been established that lowering the piezometric level of groundwater for every $10 \mathrm{~m}$ of the aquifer increases the load of the overlying layers by an average of $1 \mathrm{~kg} / \mathrm{cm}^{2}$ (Slastunov \& Koroleva, 2001).

The deposits of ferromanganese ores, copper, plumbum - zinc, rare metals, and coal, which are developed by open pit and underground methods, are constantly acting factors of both direct and indirect negative impact on the environment. One of the mediated negative impacts are harmful emissions into the atmosphere. The main air pollution comes from emissions from stationary sources of pollution, which amount to over a million tons per year. The cities: Temirtau (350.0 thousand tons per year), Balkhash (449.4 thousand tons per year), Zhezkazgan (145.0 thousand tons per year), Karaganda (63,1 thousand tons per year) which have the most polluted air environment from stationary sources (Karenov, 2006).

The major sources of atmospheric pollution are the enterprises of "Kazakhmys" Corporation (it accounts for $75 \%$ of total $\mathrm{SO}_{2}$ emissions in the metallurgical industry and $37 \%$ of the total amount of solid substances), "Mittal Steel Temirtau", "Kazzinc", as well as enterprises energy and agriculture. Emissions from mobile sources contribute their share to the pollution of the atmosphere of cities and towns. So, only emissions from motor vehicles are about 100 thousand tons per year (Karenov, 2006).

Solid particles emitted by "Kazakhmys" corporations vary in size (from 1000 to 0.1 microns) and contain heavy metals (cadmium, plumbum, zinc, copper, chromium, etc.), silicon dioxide (Baymyrzaev, 2000). The zone of influence of dust, whose concentration exceeds the MPC by 26 times, is about $10 \mathrm{~km}$. "Mittal Steel Temirtau" company accounts for $87 \%$ of total emissions of carbon dioxide, $57.6 \%$ of total emissions of nitrogen dioxide and $32.5 \%$ of solid particles emitted by the metallurgical industry. Contaminated dust containing copper, barium, zinc, nickel, cobalt, beryllium, covers residential areas and has a harmful effect on people's health. In addition, this dust is washed off with melt and rainwater, enters the groundwater, merges into relief depressions, concentrating in the plantar part of gentle slopes and the bottoms of logs and soils. Thus, the morphology of the relief distributes and redistributes solid atmospheric pollution.
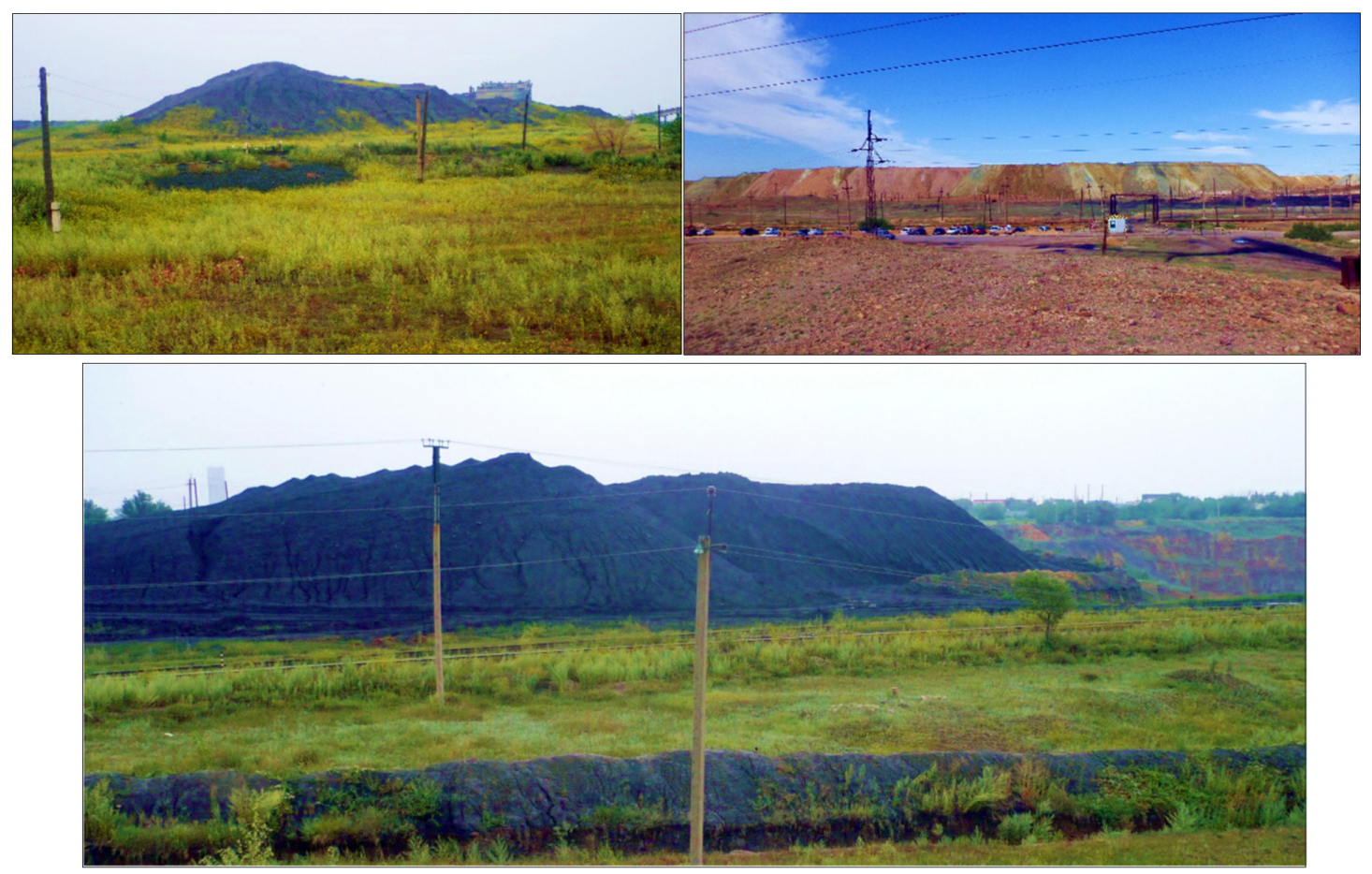

Figure 2. Mine dumps situated near Zhezkazgan, Karaganda, Balkhash cities 
The land fund of the region is about 42 million hectares, of which 45 thousand hectares of disturbed lands, 13 thousand hectares were polluted (Karenov, 2006). Mine dumps of the region - production wastes (up to 7.5 billion tons) lead to a noticeable reduction in the usable land area (more than 14.2 thousand hectares). Their height varies from $15-20 \mathrm{~m}$ to $60-80 \mathrm{~m}$, the length of some mine dumps, sometimes lined up in 5-6 rows, reaches $4-5 \mathrm{~km}$. Most part of the tailings of copper ore are located near the cities of Zhezkazgan, Karaganda, Balkhash (Figure 2).

The main sources of data and research methods on which the results and conclusions of this article were based include: a review and analysis of the bibliography on the studied topic, including statistical data, field studies and analysis of the materials obtained, analysis of cartographic material, comparative comparative and matching analysis of measurement data and social poll data (old-timers aged 45 to 90 years). Measurements were carried out on key areas within three large industrial zones (Zhezkazgan-Ulytau, Karaganda-Temirtau and Sayak-Balkhash) both in kind (field) and on topographic maps of 1: 200,000, published in 1982 and 2014 (areas were determined occupied by natural exogeodynamic processes). Field measurements were connected with the determination of the areas occupied by the manifestations of various types of negative exodynamic processes caused by anthropogenic activity.

\section{Results and discussions}

A huge impact on technomorphogenesis has a method of mining ore mass - open pit or underground. In a region dominated by the near-surface occurrence of ore bodies, the mining of the latter is carried out in open pit method, which is a more harmful way.

The method of mining changes the nature and type of technogenic effects on the components of the environment. The initial development of ores and the necessary building material was carried out by an open pit method, due to their close occurrence to the earth's surface. Large and small mining pits in the study area are more than 120 , the depth of development of which varies from 15-20 m (construction materials quarry) to 400 meters or more (ore pits).

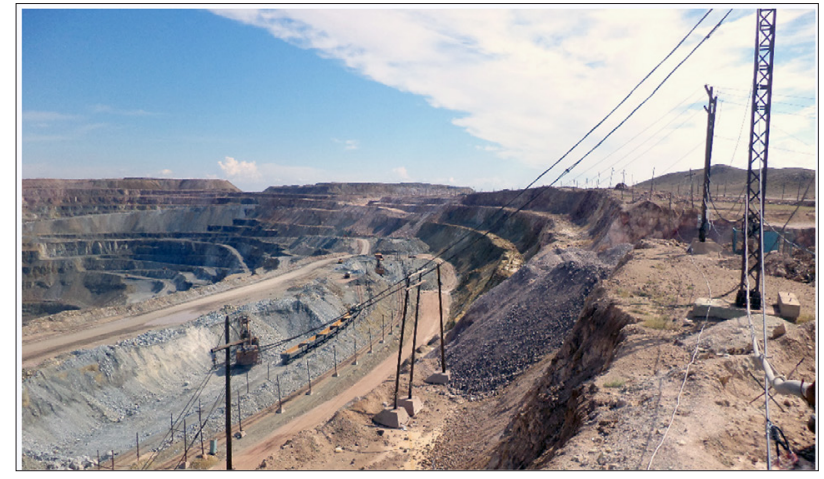

Figure 3. Kounrad quarry near the town of Balkhash

The most famous mine quarries are Kounrad and Annen. Kounrad quarry is located $30 \mathrm{~km}$ north of Balkhash. Its depth reaches $425 \mathrm{~m}$. At present, the eastern and southeastern parts of the quarry are being finalized. The ledges on the sides of the pit reach 12-17 m, the angles of the slopes of the ledges in their lower parts is more than $60^{\circ}$. Ore is mined by drilling and blasting operations. The exploded rock mass is transported by truck to the railway transport with further transportation of the rock mass to the dressing mill plant in Balkhash. The spent Annen pit, whose depth varies from 60 to $120 \mathrm{~m}$, and its length from 100 to $300 \mathrm{~m}$, is intensively destroyed, being filled with hazardous waste, which are a source of destabilization of the ecological situation (Figure 5).

Developments by the open pit method lead to the development of extremely dangerous processes of exomorphogenesis - linear and plane erosion, landslides, landfall, deflation, etc., which are observed on the sides and bottoms of mining pits, on the slope surfaces of the dumps (Figure 2-3). Unfixed material dumps tangible negative environmental and social consequences as a result of waving fine-grained material, sedimentation, discharging and erosion by their streaming erosion of their sides. All this material spreads far and accumulates outside dumps (up to $15-30 \mathrm{~km}$ ), overlaps the soil horizon, thereby causing man-made desertification of land, which greatly changes the natural conditions of mining areas.

Deformations of overlying layers of rocks and the formation of subsidence troughs, bending and shearing of layers, roof dips over the produced layers are associated

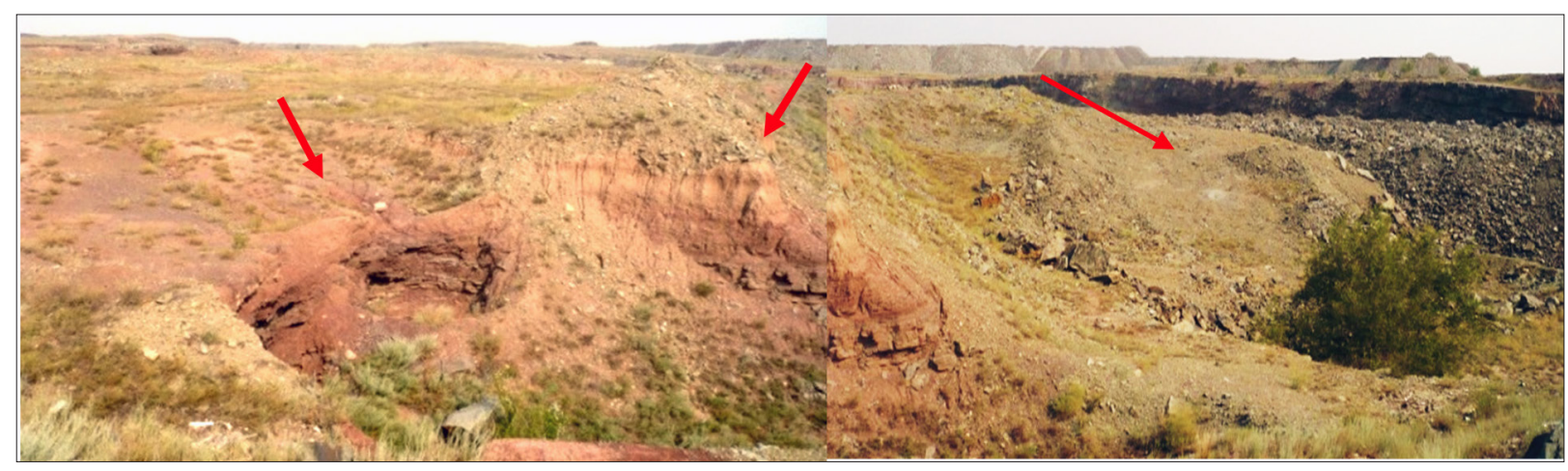

Figure 4. Dips over mine voids (near the t. Rudnik, Zhezkazgan ore field). The arrows indicate the places of dips 
with underground mining. An example of the deformation of the overlying layers can be clearly expressed in relief reliefs above the mine voids in the populated locality Rudnik near the town of Satpayev (Figure 4). As a result of these subsidence, ditches were formed with a length of up to $100 \mathrm{~m}$, the depth of which reached $8-12$ to $28-40$ or more meters. The continuation of this process has necessitated, for security reasons, the resettlement of the villagers of the Rudnik to safer areas.

Drilling and blasting operations cause intense cracking and crushing of rocks, leading to the transformation of surface water runoff, flooding and waterlogging of subsided areas of the earth's surface above underground workings (Alpysbaev \& Karatorgaev, 2001).

The load on the natural, including the geomorphological environment due to the coal mining industry is noted within the entire Karaganda basin, the total area of which is more than 4 thousand $\mathrm{km}^{2}$. During the underground mining, a large environmental risk is connected with sudden coal emissions and gas-dynamic phenomena. According to reports, in the Karaganda basin such emissions reach from a few meters to $550 \mathrm{~m}$ (Saginov, 1995). Gases, which has a particular hazard, containing sulfur that are released in the mines during coal mining (Alpysbaev \& Karatorgaev, 2001; Saginov, 1995).
In the Karaganda coal basin, sudden explosions of gases led to catastrophic debris of treatment facilities, which contributed to the rapid deformation of the earth's surface. Huge spoil tips, formed over a long period (over 65 years) of coal mining, became a permanent negative factor in the Karaganda region. The smallest particles of spoil tips are carried by the wind and surface run off for hundreds of meters and even the first kilometers, contaminating and destroying the natural fertility of the soil and the density of vegetation, thereby enhancing the processes of erosion and deflation. Underground coal mining in Maykuduk (a suburb of Kargandy) caused the subsidence of the earth's surface within the urban area, with the formation of sinkholes and subsequent watering and waterlogging.

Ore and coal mining of surface and subsurface parts of the geological base, especially during quarrying, dumps of industrial processing of coal and ores in arid and subarid natural conditions has led and lead to the formation of lifeless lands - the so-called technological badlands (Figure 5,6$)$. On the sides of almost all quarries, gravitational processes, erosion and deflation processes are developing, and near quarries, subsidence processes of an areal character is developing (Figure 7). In some places, drawdowns reach $8-15 \mathrm{~m}$.

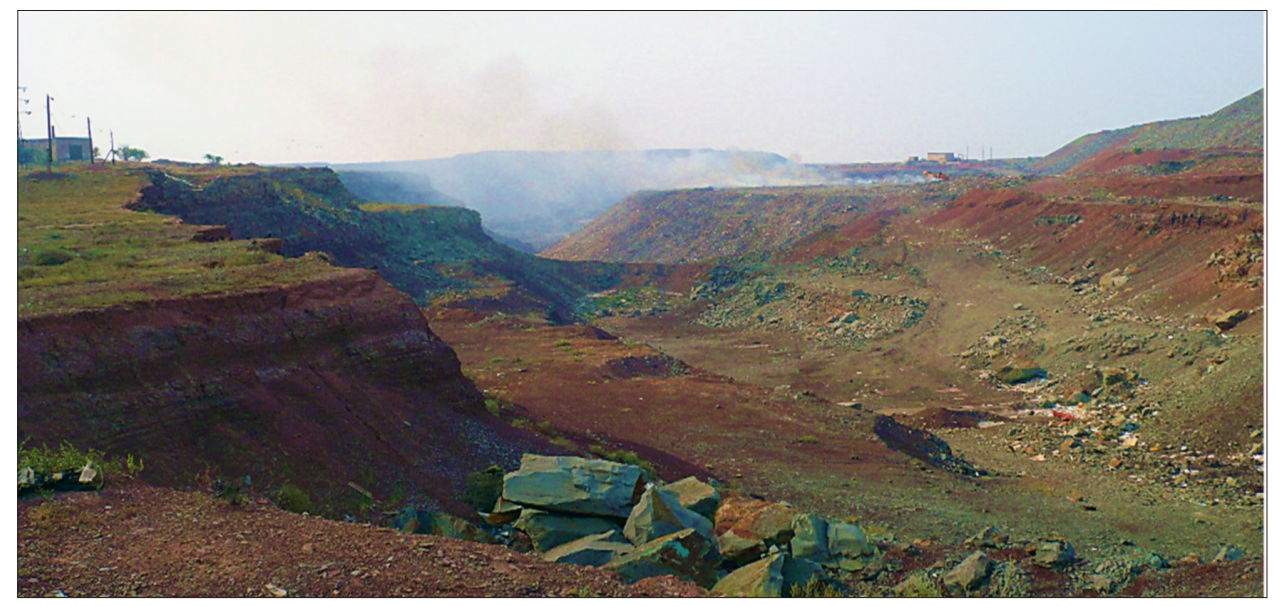

Figure 5. Technological badland of the Annen quarry (2 km from t. Satpayev)

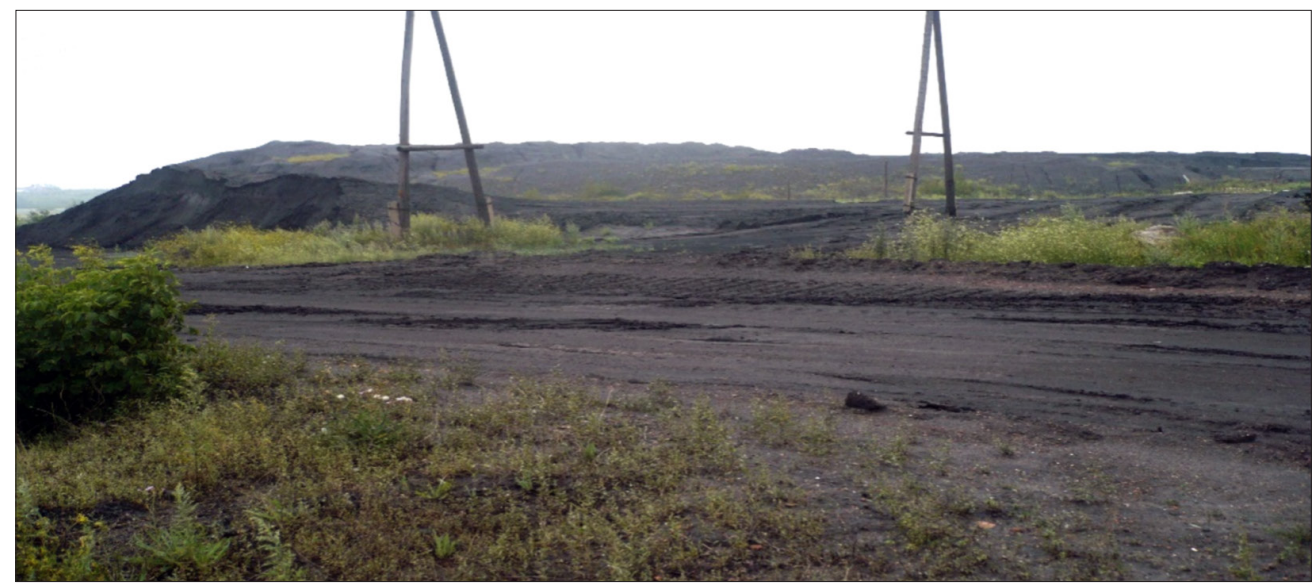

Figure 6. Technological badlands within the boundaries of the Karaganda industrial zone 


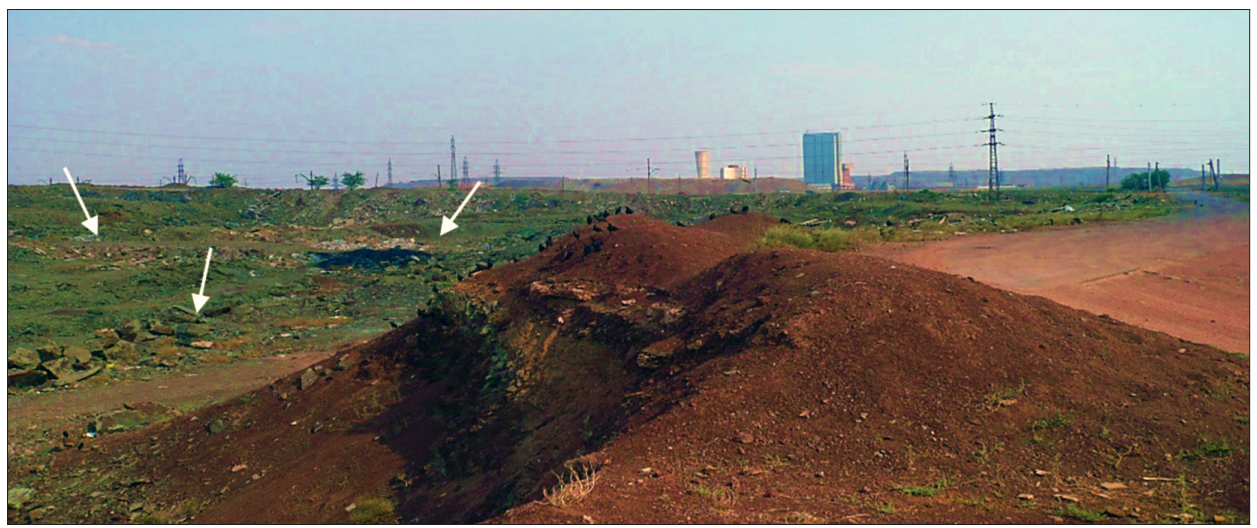

Figure 7. The area of subsidence of the earth's surface near Annen quarry (2 km from t. Satpayev )

In arid conditions, the hazardous consequences of mining production should include the transformation of the hydrogeological situation within the ore fields. The ores leading to the formation of deep dips and subsidence (their area sometimes reaches hundreds of $\mathrm{km}^{2}$ ) contribute to the deterioration of water quality at the one time. For example, at the beginning of the underground development of Zhezkazgan copper field (up to a depth of $100 \mathrm{~m}$ ), the waters were fresh, rarely slightly saltish, characterized by a bicarbonate and bicarbonate-sulphate composition. With the increase in the depth of ore development (200-300m and more), sulfate-chloride waters with relatively high salts from $2.4-3.6 \mathrm{~g} / \mathrm{l}$ to $109,15 \mathrm{~g} / \mathrm{l}$ began to flow into the zone of circulation of mine water, especially in areas of tectonic faults (Gorshkov, 1982; Alpysbaev \& Karatorgaev, 2001; Saginov, 1995).

Enriched with harmful microelements (plumbum, zinc, iron and copper, mercury and arsenic, etc.), mine water becomes unsuitable for economic using. In the mining areas of the research territory, mine water leads to groundwater pollution, swamping, flooding and salinization within the settlements, significantly reducing the area suitable for economic use of land (Zhezkazgan c., Zhayrem t., Aksu v. etc.) (Baymyrzaev, 2000; Gorshkov, 1982; Saginov, 1995; Sahiev, 2016).

Methods for determining absolute estimates of the degree of danger of geomorphological processes in the scientific literature are missing. Relative estimates of the degree of danger of a process are used. In this work, a comparative assessment of the danger of geomorphological processes was also used - the result of a comparison of data from field and cartographic measurements of the manifestation of processes was determined by the coefficient of geomorphological danger (Table 1) (Bekseitova et al., 2016):

In the specified Table $1 K_{g d}=A A / N P, K_{g d}$ - the coefficient of geomorphological danger, $A A$ - anthropogenic activity, $N P$ - natural exodynamic processes.

Based on the data we obtained, a cartographic model of geomorphological risks was constructed in a key area of the Ulytau-Zhezkazgan mining and industrial zone (Figure 8).
Table 1. The degree of manifestation of geomorphological risks (Bekseitova et al., 2016)

\begin{tabular}{|c|c|c|c|}
\hline $\begin{array}{l}\text { Morphological } \\
\text { type of relief }\end{array}$ & $\begin{array}{l}\text { Subtype of } \\
\text { relief }\end{array}$ & $\begin{array}{c}\text { the coefficient } \\
\text { of geomor- } \\
\text { phological } \\
\text { danger }\left(K_{g d}=\right. \\
A A / N P)\end{array}$ & $\begin{array}{l}\text { The degree of } \\
\text { manifestation } \\
\text { of geomor- } \\
\text { phological } \\
\text { risks }\end{array}$ \\
\hline \multirow{2}{*}{$\begin{array}{l}\text { Plain of } \\
\text { accumulative } \\
\text { storage }\end{array}$} & $\begin{array}{l}\text { Eluvial-prolu- } \\
\text { vial plains }\end{array}$ & \multirow{2}{*}{$0.75-0.55$} & \multirow{2}{*}{ Average } \\
\hline & $\begin{array}{l}\text { Alluvial-Pro- } \\
\text { luvial plains }\end{array}$ & & \\
\hline \multirow{2}{*}{$\begin{array}{l}\text { Dissected } \\
\text { denudation } \\
\text { and } \\
\text { accumulative } \\
\text { plains }\end{array}$} & $\begin{array}{l}\text { Hilly and } \\
\text { rolling plains }\end{array}$ & $0.55-0.40$ & Significant \\
\hline & $\begin{array}{l}\text { Deluvial-pro- } \\
\text { luvial plume } \\
\text { plains }\end{array}$ & $<0.40$ & High \\
\hline \multirow{2}{*}{$\begin{array}{l}\text { Denudation } \\
\text { plains of } \\
\text { various } \\
\text { morphology }\end{array}$} & $\begin{array}{l}\text { Flat sublime } \\
\text { plains }\end{array}$ & \multirow{2}{*}{$1.0-0.75$} & \multirow{2}{*}{ Weak } \\
\hline & Shallow hills & & \\
\hline \multirow{2}{*}{$\begin{array}{l}\text { Foothill } \\
\text { dissected } \\
\text { plains and } \\
\text { island } \\
\text { lowlands }\end{array}$} & $\begin{array}{l}\text { Foothill plains } \\
\text { with ridge - } \\
\text { hill dismem- } \\
\text { berment }\end{array}$ & \multirow[t]{2}{*}{1.0} & \multirow[t]{2}{*}{ Very weak } \\
\hline & $\begin{array}{l}\text { Island } \\
\text { lowlands }\end{array}$ & & \\
\hline
\end{tabular}

Based on the comparison of the data reflected in Table 1 with the spatial distribution of types of environmental management, Table 2 was compiled (Bekseitova et al., 2016), which shows the degree of dependence of the geomorphological environment on the nature of environmental management.

The development of a method for determining comparable levels of assessment of the geomorphological environment, affecting to a large extent all other components of the environment, is based on the results of research and calculation of the data given above. Table 3 shows the levels of environmental assessment in the industrial zones of the region in five grades: "good", "satisfactory", "unsatisfactory", "critical" and "crisis". 


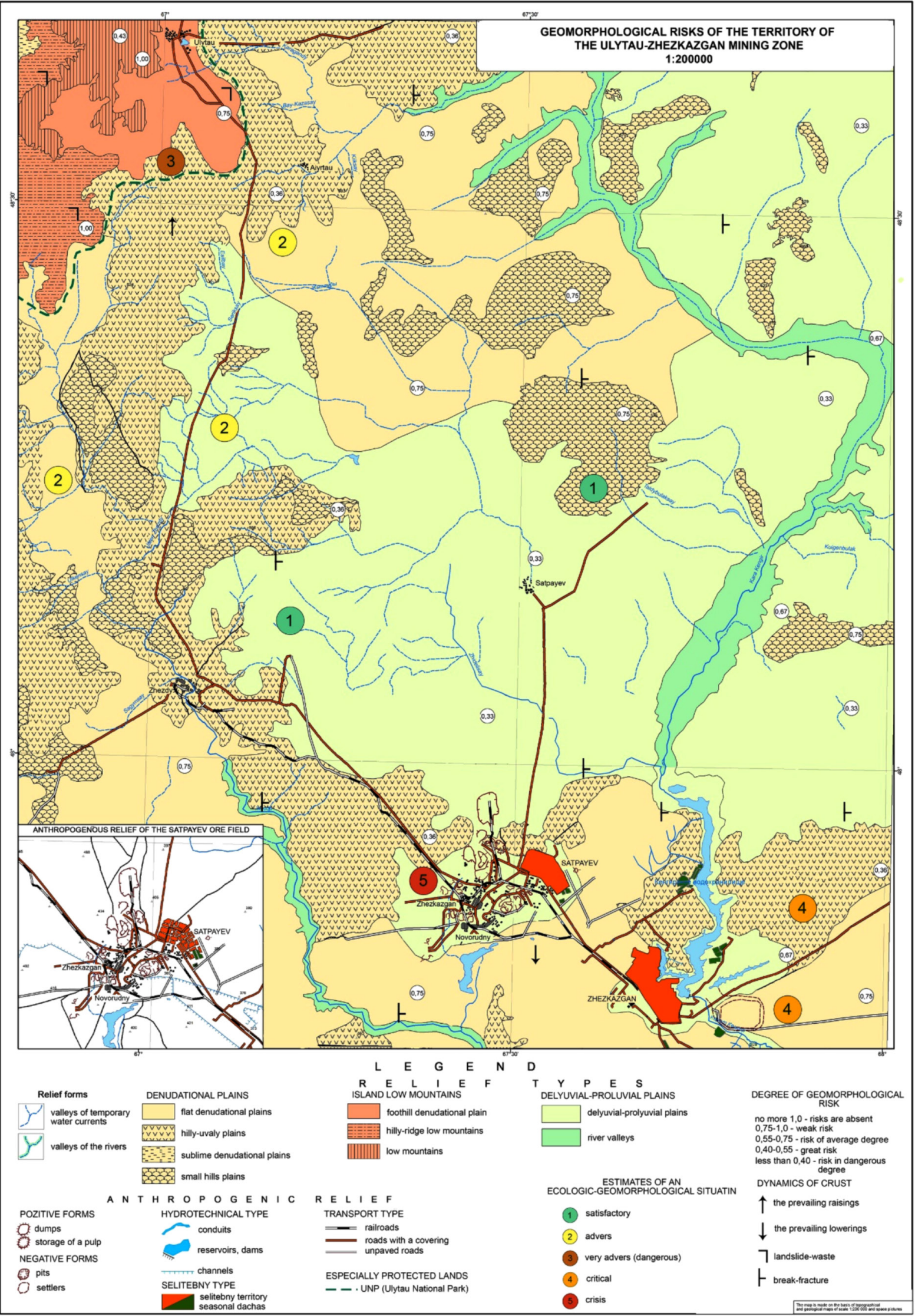

Figure 8. Map of geomorphological risks and estimations of ecologic-geomorphological situations of the territory Ulytau-Jezkazgan mining zone (Department of Cartography and Geoinformatics, Al-Farabi Kazakh National University, Almaty, the RK, 2018) 
Table 2. Types of nature management and the degree of environmental disturbance (Bekseitova \& Koshim, 2017)

\begin{tabular}{|c|c|c|c|c|c|}
\hline \multirow{2}{*}{$\begin{array}{c}\text { Character of } \\
\text { Natural resource } \\
\text { management }\end{array}$} & \multirow{2}{*}{$\begin{array}{l}\text { Type of Natural } \\
\text { resource } \\
\text { management }\end{array}$} & \multirow{2}{*}{$\begin{array}{l}\text { Types of conversion } \\
\text { lands }\end{array}$} & \multicolumn{3}{|c|}{ Environmental disturbance } \\
\hline & & & weak & middle & strong \\
\hline \multirow[t]{2}{*}{ Mining industrial } & $\begin{array}{l}\text { Mining (mining and } \\
\text { ore dressing) }\end{array}$ & $\begin{array}{l}\text { - Quarries } \\
\text { - Underground mining } \\
\text { - Mining dumps } \\
\text { - Tailings } \\
\text { - Processing industry enterprises } \\
\text { - Recycling industry enterprises }\end{array}$ & + & $\begin{array}{l}+ \\
+ \\
+\end{array}$ & $\begin{array}{l}+ \\
+\end{array}$ \\
\hline & Hydrotechnical & $\begin{array}{l}\text { - Reservoirs, including household waste } \\
\text { - Channels }\end{array}$ & & $\begin{array}{l}+ \\
+\end{array}$ & \\
\hline \multirow[b]{2}{*}{ Urban-economic } & Urban & $\begin{array}{l}\text { - Large agglomerations } \\
\text { - Cities }\end{array}$ & & $\begin{array}{l}+ \\
+\end{array}$ & + \\
\hline & Rural & $\begin{array}{l}\text { - Urban villages } \\
\text { - Rural villages } \\
\text { - Recreation objects }\end{array}$ & $\begin{array}{l}+ \\
+\end{array}$ & + & \\
\hline \multirow{2}{*}{ Agricultural } & Agrotechnical & $\begin{array}{l}\text { - Rainfed farming } \\
\text { - Irrigated farming }\end{array}$ & & + & + \\
\hline & Pasture & - Pastures & & & \\
\hline \multirow{2}{*}{$\begin{array}{l}\text { Transport and } \\
\text { communication }\end{array}$} & Transport & $\begin{array}{l}\text { - Railways } \\
\text { - Car roads }\end{array}$ & & & $\begin{array}{l}+ \\
+\end{array}$ \\
\hline & Communication & $\begin{array}{l}\text { - Power lines } \\
\text { - Product lines }\end{array}$ & $\begin{array}{l}+ \\
+\end{array}$ & & \\
\hline \multirow{2}{*}{$\begin{array}{l}\text { Military and } \\
\text { scientific strategic }\end{array}$} & Poligonal & - Testing polygons & & & + \\
\hline & Rocket - Space & - Spaceport & & & + \\
\hline
\end{tabular}

Table 3. Levels of assessment of the degree of geomorphological disturbances in the Temirtau-Karaganda mining zone in Central Kazakhstan

\begin{tabular}{|c|c|c|c|c|c|c|c|c|c|c|c|c|}
\hline \multicolumn{12}{|c|}{ The degree of assessment of natural components } & \multirow{3}{*}{$\begin{array}{l}\text { Top recommendations } \\
\text { for improving the } \\
\text { geomorphological } \\
\text { situation and the } \\
\text { environment }\end{array}$} \\
\hline \multirow{2}{*}{$\begin{array}{l}\text { The nature } \\
\text { of the } \\
\text { geomor- } \\
\text { phological } \\
\text { situation }\end{array}$} & \multicolumn{5}{|c|}{ relief } & \multirow{2}{*}{$\begin{array}{c}\text { State of land } \\
\text { and water } \\
\text { resources }\end{array}$} & \multicolumn{5}{|c|}{ land and water } & \\
\hline & Good & $\begin{array}{l}\text { Satis- } \\
\text { factory }\end{array}$ & $\begin{array}{l}\text { Unsa- } \\
\text { tisfac- } \\
\text { tory }\end{array}$ & $\begin{array}{l}\text { Cri- } \\
\text { tical }\end{array}$ & $\begin{array}{l}\text { Cry- } \\
\text { sis }\end{array}$ & & Good & $\begin{array}{c}\text { Satis- } \\
\text { factory }\end{array}$ & $\begin{array}{l}\text { Unsa- } \\
\text { tisfac- } \\
\text { tory }\end{array}$ & $\begin{array}{c}\text { Criti- } \\
\text { cal }\end{array}$ & $\begin{array}{l}\text { Cry- } \\
\text { sis }\end{array}$ & \\
\hline 1 & 2 & 3 & 4 & 5 & 6 & 7 & 8 & 9 & 10 & 11 & 12 & 13 \\
\hline $\begin{array}{l}\text { No change, } \\
\text { minor } \\
\text { changes } \\
\text { in relief } \\
\text { formation } \\
\text { processes }\end{array}$ & + & & & & & $\begin{array}{l}\text { Unchanged, } \\
\text { minor } \\
\text { changes } \\
\text { in natural } \\
\text { resource use }\end{array}$ & + & & & & & $\begin{array}{l}\text { Possible improvement } \\
\text { of the environment } \\
\text { without significant } \\
\text { costs. The stabilized } \\
\text { activity of the } \\
\text { economic structure. }\end{array}$ \\
\hline $\begin{array}{l}\text { Significant } \\
\text { changes } \\
\text { in the } \\
\text { formation of } \\
\text { relief }\end{array}$ & & + & & & & $\begin{array}{l}\text { Noticeable } \\
\text { changes } \\
\text { in the use } \\
\text { of natural } \\
\text { resources }\end{array}$ & & + & & & & $\begin{array}{l}\text { It is possible to } \\
\text { improve the use } \\
\text { of land resources, } \\
\text { including agricultural } \\
\text { technologies. } \\
\text { Monitoring of land } \\
\text { resources is required. }\end{array}$ \\
\hline $\begin{array}{l}\text { Degradation } \\
\text { of individual } \\
\text { landscapes, } \\
\text { violation of } \\
\text { the mor- } \\
\text { pholitho- } \\
\text { genic basis }\end{array}$ & & & + & & & $\begin{array}{l}\text { Reduced } \\
\text { land use } \\
\text { efficiency }\end{array}$ & & & + & & & $\begin{array}{l}\text { Improvement of } \\
\text { environmental } \\
\text { activities is needed. It } \\
\text { is necessary to monitor } \\
\text { geodynamic processes } \\
\text { in the development } \\
\text { of all types of solid } \\
\text { minerals. }\end{array}$ \\
\hline
\end{tabular}




\begin{tabular}{|c|c|c|c|c|c|c|c|c|c|c|c|c|}
\hline 1 & 2 & 3 & 4 & 5 & 6 & 7 & 8 & 9 & 10 & 11 & 12 & 13 \\
\hline $\begin{array}{l}\text { Significant, } \\
\text { sometimes } \\
\text { irreversible } \\
\text { changes in } \\
\text { the relief }\end{array}$ & & & & + & & $\begin{array}{l}\text { A } \\
\text { significant } \\
\text { reduction } \\
\text { in the } \\
\text { efficiency of } \\
\text { use of land } \\
\text { and water } \\
\text { resources }\end{array}$ & & & & + & & $\begin{array}{l}\text { Expensive, sometimes } \\
\text { expensive, costs are } \\
\text { required for the } \\
\text { reorganization of } \\
\text { certain structures of } \\
\text { the mining and mining } \\
\text { industries }\end{array}$ \\
\hline $\begin{array}{l}\text { Degradation } \\
\text { of } \\
\text { landscapes, } \\
\text { the } \\
\text { formation } \\
\text { of anthro- } \\
\text { pogenic } \\
\text { relief }\end{array}$ & & & & & + & $\begin{array}{l}\text { Economic } \\
\text { crisis }\end{array}$ & & & & & + & $\begin{array}{l}\text { Fundamental } \\
\text { reorganization of the } \\
\text { regional economy }\end{array}$ \\
\hline
\end{tabular}

\section{Conclusions}

The lands disturbed by geological exploration, mining and exploitation of coal and ores occupy vast territories, including the entire serving infrastructure. Thus, mining production caused violations to one degree or another in all spheres of the territory of Central Kazakhstan - as a unified regional geosystem of platform-denudation plains:

1. Open pit and underground mining have both direct and indirect effects on the structural components of geosystems, including the development of dangerous geomorphological and dynamic processes (man-made seismicity, wind and water erosion, karst and suffusion), which are particularly active in mining zones. The degradation of soil and vegetation caused by leveling man-made rocks on vast areas of mining and residential areas, the development of fine earth from unfixed surfaces of mining dumps, which leads to increased desertification, as well as the deterioration of the ecology of the region as a whole.

To reduce the danger of geomorphic processes and the degradation of soil and vegetation as a result of the plantation of the earth's surface by technogenic rocks, it is necessary to create a special program for the inventory and assessment of land in the mining and industrial zones of Central Kazakhstan, which would be aimed at:

- preservation of the sides of mine quarries and dumps by fixing them with a special solution and their subsequent recultivation by terracing and gardening.

- termination of the practice of leveling the earth's surface technogenic rocks, especially near residential areas.

2. Pollution and depletion of surface and groundwater actively used in the industrial processing of ore mass, depletion of reserves and lowering the level of groundwater desalinated water, disturbances in the circulation of groundwater caused by explosive technology and open pit mining.

To solve the problem of pollution and depletion of the surface and groundwater of the region:

- update the entire registry of both groundwater and surface water sources;
- organize monitoring of the quality of these waters on an ongoing basis;

- develop recommendations for their use, taking into account the results of monitoring.

\section{References}

Abalakov, A. D., \& Kuzmin, S. B. (1998). Ehkologicheskaya ocenka ehkomorfosistem. Geoehkologiya, 3, 28-40.

Abalakov, A. D. (2007). Ehkologicheskaya geologiya. Irkutsk: Izdatel'stvovo Irkutskogo gosudarstvennogo universiteta.

Adamenko, O. M. (1991). Rol'i mesto izucheniya vzaimodejstviya geomorfologicheskih processov i okruzhayushchej sredy v ehkologicheskom monitoringe. Geomorfologicheskie processy i okruzhayushchaya sreda, 1, 4-8.

Akiyanova, F. Z. H. (2000). Zakonomernosti sovremennogo rel'efoobrazovaniya kazahstanskogo Prikaspiya i problemy ehkologii. In Materialy pervogo Central'no-Aziatskogo geotekhnicheskogo simpoziuma (s. 864-868). Astana.

Alpysbaev, K. A., \& Karatorgaev, M. H. (2001). Issledovania problem podderghania ochistnogo prostranstva so sloghnymi gorno-geologicheskimi usloviami Zhezkazganskogo mestoroghdenia. Vestnik Zhezkazganskogo universiteta im. O. A. Baykonurova, 2(2), 192-194.

Azbukina, E. N., \& Fedorov, N. P. (1975). K voprosu o znachenii tekhnogennogo faktora v razvitii sovremennogo rel'efa. Geografiya, $18,75-85$.

Baborykin, M. U. (2013). Monitoringopasnyh geologicheskih processov na lineinyh obektah. Ingenernye yzyskaniya, 10-11, 44-55.

Barsch, D. (1990). Geomorphology and geoecology. Geomorphology New Folge, 79, 39-49.

Baymyrzaev, K. M. (2000). Prirodno-resursny potencial Centralnogo Kazakhstana iproblem ego racionalnogo osvoenia. Almaty.

Bekseitova, R. T., Veselova, L. K., Kasymkanova, K. M., Jangulova, G. K., Tumajanova, S., Bektur, B., \& Beisembina, G. T. (2016). Preliminary discussions on impacts of industrial induced factors on the environment of central Kazakhstan. Journal of Landscape Ecology, 9(44), 50-65. https://doi.org/10.1515/jlecol-2016-0014

Bekseitova, R. T., Veselova, L. K., Duisebaeva, K. J., Baiandinova, S. M., \& Bekkulieva, A. (2012) Antropogennye factory 
relefoobrazovaniia v predelah platformenno-denudacionnyh ravnin aridnoi zony Kazahstana (Centralnyi Kazahstan). Vestnik KazGU, seriya geograficheskaya, 13-20.

Bekseitova, R. T., \& Koshim, A. G. (2017). Tauken ondirisi aimagynyn qaupsizdik maselesi (Ortalyq Qazaqstan). Vestnik KazGU, seriya geograficheskaya, 1(44), 98-103.

Bocco, G., Velbzquez, A., \& Siebe, C. (2005). Using geomorphologic mapping to strengthen natural resource management in devoloping countries. The case of rural indigenous communities in Michoacan, Mexico. Catena, 3, 239-254. https://doi.org/10.1016/j.catena.2004.12.003

Charles, J. A., Hughes, D. B., \& Burford, D. (1984). The effect of a rise water table on the settlement of backfill of Horsley restored opencast coal mining site, 1973-1983. In J. D. G. Cardiff (Ed.), Proceedings of the 3 rd international conference on ground movements and structures (pp. 423-442). London: Pentech Press.

Efremov, U. V. (2008). Geomorfologicheskaya kartografiya: uchebnoe posobie. Krasnodar: Izdatel'stvo KubGU.

Ermolov, A. A. (2014). Issledovanie opasnyh ekzogennyh geologicheskih processov v rankah kompleksnyh ingenernyh izyskanii i proizvodstvennogo monitoringa na lineinyh ob'ektah. Ingenernyh izyskaniya, 12, 39-40.

Eszhanova, A. S. (2010). Klassifikaciya ehkzogennyh processov $v$ svyazi s ocenkoj geomorfologicheskogo riska. Almaty: Vestnik KazNPU.

Evseeva, N. S. (2012). Ehkologicheskaya geomorfologiya: temy referatov i spisok literaturnyh istochnikov. Tomsk.

Faizov, K. S. (2000). Antropogennoe opustynivanie pochv RK. Almaty.

Fonstad, M. A., Dietrich, J. T., Courville, B. C., Jensen, J. L., \& Carbonneau, P. E. (2013). Topographic structure from motion: a new development in photogrammetric measurement. Earth Surface Processes and Landforms, 38(4), 421-430. https://doi.org/10.1002/esp.3366

Golubev, E. V. (2008). Geomorfologicheskie issledovaniya pri osvoenii neftegazovyh mestorozhdenij Sibiri. Moscow: MGU.

Gorshkov, S. P. (1982). Eczodinamicheskie proccesy osvoennyh territoriy. Nedra.

Graham, K. J., \& Kinney, G. I. (1980). A practical safety analysis system for hazads control. Journal of Safety Research, 1, 12-20.

Grishin, A. S., \& Novikov, V. N. (2000). Ehkologicheskaya bezopasnost. Moscow: Grand.

Gurney, S. (2005). Mapping the spatial distribution of geomorphological processes in Okstindan area of northern Norway, using Geomorphic Proces units as derived from remote sensing and ground survey. Fennia, 1, 1-14.

Hotuncev, U. L. (2004). Ehkologiya i ehkologicheskaya bezopasnost'. Moscow: Izdatel'skij centr "Akademiya".

Institute of geography. (2010). The national atlas of the Republic of Kazakhstan. Retrieved from https://ingeo.kz/?p=3643\& lang=en

Kaiser, A., Neugirg, F., Rock, G., Müller, C., Haas, F., Ries, J., \& Schmidt, J. (2014). Small-scale surface reconstruction and volume calculation of soil erosion in complex Moroccan gully morphology using structure from motion. Remote Sensing, 6(8), 7050-7080. https://doi.org/10.3390/rs6087050

Karenov, R. S. (2006). Perspektivy snijeniya negativnogo vozdeystviya ugolnoy promyshlennosti na ekologiu Kapagandinskoy oblasti. Vestnik KarGU, 2, 12-15.
Korkin, S. E., \& Talyneva, O. U. (2015). Regional'nye aspekty proyavleniya opasnyh prirodnyh ehkzodinamicheskih processov dlya territorii Srednego Priob'ya. In Materialy Vserossijskoj konferencii "VII SHchukinskie chteniya" (s. 28-31). Moscow.

Kushimova, A. G. (2003). Sostoyanie i ehkologicheskie problemy neftedobyvayushchej otrasli Prikaspijskogo regiona. In $\mathrm{Ma}$ terialy XXVII Plenuma Geomorfologicheskoj komissii RAN $i$ VII Vserossijskogo nauchnogo seminara "Samoorganizaciya $i$ dinamika geomorfosistem" (s. 272-274). Tomsk: Izdatel'stvo Instituta optiki atmosfery SO RAN.

Lvovich, M. I. (1986). Voda i ghizn (Vodnye resursy, ih preobrazovanie i ohrana). Moscow: Mysl.

Medeu, A. R. (2010). Prirodnye usliviya i resursy. Almaty, Respulika Kazahstan: "Print-S".

Milanovich, P. (2000). Geological engineering in karst. Belgrade, Serbia: Zebra Publishing Ltd.

Nysanbek, U. M. (2003). Konceptual'nye problemy ehkologicheskoj bezopasnosti v Respublike Kazahstan. Analytic, 5, 1-17.

Pecsi, M. (1986). Ecological-geomorphological researches Hungary. Budapecht.

Rodionov, A. I. (2000). Tekhnologicheskie processy ehkologicheskoj bezopasnosti (osnovy ehnvajronmentalistiki). Kaluga: Izdatel'stvo N. Bochkarevoj.

Saginov, A. C. (1995). Problemy razrabotki mestoroghdeniy poleznyh iskopaemyh. Almaty.

Sahiev, S. E. (2016) Ekologicheskaya bezopasnost' odin iz osnovnyh strategicheskih komponentov nacional noj bezopasnosti Respubliki Kazahstan. Almaty.

Shogren, J. F., \& Grocken, T. D. (1999). Risk and its consequences. Journal Environmental Economy and Management, 37(1), 45-51. https://doi.org/10.1006/jeem.1998.1059

Simonov, U. G. (1990). Inzhenernaya geomorfologiya. Indikacionnyj analiz i metody issledovaniya. Moscow: Izd-vo MGU.

Simonov, U. G., \& Gladkevitch, G. I. (1995). Concept of the ecological certification of territories on the asis of land use structure. In Global Changes and Geography (s. 112-113). Moscow.

Simonov, U. G. (2005). Geomorfologiya. SPb.: Piter.

Simonov, U. G., \& Simonova, T. U. (2013). Fundamentalnye problemy antropogennoj geomorfologii. Geomorfologiya, 3, 3-11.

Slastunov, S. V., \& Koroleva, V. N. (2001). Gornoe delo $i$ okrughaushaia sreda. Moscow: Logos.

Smetanin, V. I. (2000). Zashchita okruzhayushchej sredy ot othodov proizvodstva i potrebleniya. Moscow: Kolos.

Smith, M. W., \& Vericat, D. (2015). From experimental plots to experimental landscapes: topography, erosion and deposition in sub-humid badlands from Structure-from-Motion photogrammetry. Earth Surface Processes and Landforms, 40(12), 1656-1671. https://doi.org/10.1002/esp.3747

Toy, J. (1984). Geomorphoiogv of surfacemined lands in Western United States. Developments and Applications of Geomorphology, 133-170. https://doi.org/10.1007/978-3-642-69759-3_5 Volkov, A. V. (2009). Ustoichivost' rel'efa v obstanovke tehnogennogo vozdeistviya (na primere gazotransportnogo stroitel'stva). Estestvenny nauki, 3, 18-22.

Voskresenskiy, I. S., Suchilin, A. A., Ushakova, L. A., Shaforostov, V. M., \& Entin, A. L. (2018). Monitoring rel'efa trassy magictral'nogo truboprovoda $\mathrm{v}$ centre Russkoi ravniny $\mathrm{s}$ primeneniem distancionnyh i geoinformacionnyh metodov. Geograficheskaya, 2(49), 50-61. 